and general practitioners. British Medical Journal, 299, 1382.

KERR, M. S. D. (1990) Psychiatric discharge summaries. British Medical Journal, 300, 260-261.

\section{Stinking wards}

\section{DeAR SiRs}

It is ironic that the letter from Dr Azuonye (Psychiatric Bulletin, July $1990,14,431$ ) should appear in the same issue as an interview with Dr Alex Baker, in which he describes the formation of the Hospital Advisory Service, latterly becoming the Health Advisory Service.

This organisation monitors services for the elderly and the mentally ill in England and Wales, paying attention to the environment in which people are living as well as the professional services devoted to their care. Among many other matters to be considered is the presence of homely and comfortable hospital accommodation. The presence of large areas of vinyl flooring is more in keeping with an emphasis on reduction in domestic tasks than achieving an acceptable domestic environment.

One cannot ignore the facts of clinical reality, and while every effort should be made to reduce incontinence by an effective range of practices, aided by a suitably trained adviser, accidents will happen. It may well be that deep-pile carpeting is not the floor covering of choice, but there are many carpet-like fabrics which are amenable to cleaning, particularly if there are sufficient staff to achieve this rapidly.

The answer to Dr Azuonye's problem must be prevention of incontinence, insofar as this is possible, and the use of easy-clean, synthetic simulated wool carpets for comfort and appearance.

NHS Health Advisory Service

Philip SeAger

Sutherland House

29-37 Brighton Road

Sutton, Surrey SM2 5AN

DeAR Sirs

Dr Azuonye recommends in his letter (Psychiatric Bulletin, July 1990, 14, 431) that psychogeriatric wards must have lino floor coverings to avoid unpleasant smells. He is quite wrong.

The Scottish Hospital Advisory Service has been conducting a crusade for carpeted wards for the best part of two decades, a crusade which has been increasingly successful. We can direct Dr Azuonye to psychogeriatric and geriatric wards where carpets have been down for several years and there are no offensive odours. To achieve this requires three things.

Firstly, the carpets should be appropriate for the task: there are several satisfactory brands. Secondly, a speedily available system of carpet cleaning and the domestic staff to use it must be at hand. Thirdly, a modern system of incontinence management has to be in use.

Given these three facilities, there is no more need to floor a psychogeriatric ward with lino than there is to do the same for a dwelling house containing an incontinent child.

A. W. DRummond

Director

Scottish Hospital Advisory Service

21 Hill Street

Edinburgh EH2 3JP

\section{DeAr Sirs}

I was interested but shocked to read I. O. Azuonye's letter 'Stinking wards' (Psychiatric Bulletin, July $1990,14,431)$.

Lino is, of course, appropriate in the kitchen, bathroom and toilet of any hospital ward. However I feel it is sterile, unhomely and unnecessary to have it in any living area such as the lounge or bedroom. Instead with a carefully planned, individualised and well staffed nursing plan I have found urine and faecal incontinence is acceptably managed on many carpeted wards for elderly mentally ill people.

I think it should be established that continuing care areas for all long-term residents be suitably carpeted.

May I finally add that I have never been fortunate enough to have worked anywhere in the NHS where there are "deep-pile carpets" - not even in the nurses' home or doctors' mess.

Paediatric Unit

M. Felicity J. Young

The London Hospital (Mile End)

Bancroft Road, London El

\section{Consent and the mentally handicapped}

DEAR Sirs

Dr Race raises an extremely interesting point regarding the difficulties of obtaining consent to treatment for a 29-year-old woman with mental handicap and manic depressive psychosis, whose parents objected to treatment with lithium carbonate on the grounds that it was a "toxic drug" (Psychiatric Bulletin, July $1990,14,429)$. I see two possible ways of resolving this issue. The first follows on from the judgement of the Law Lords in the case of $F \mathbf{v}$ Berkshire Health Authority (Dyer, 1989) and the second is through the provisions of the Mental Health Act 1983.

As Bicknell (1989) points out, adults with mental handicap cannot give valid consent for treatment and no-one else, including parents, can give it on their behalf. The judgement by the Law Lords in July 1989 